\title{
Hats On, Hats Off
}

\section{CLAIR HUghes}

INDEPENDENT SCHOLAR

A certain amount of eccentricity in dress is allowed, even expected, in artists, poets and assorted bohemians. Their hats tend to be particularly eccentric. 'Funny, isn't it,' Mr Bolder observed to his friend Fred Willis, the hatter, 'that people who paint pictures think it's proper that they should act barmy? Hats like horses wear in summer.'1 A floppy felt or straw, when Victorian manhood was ramrod-stiff in top hats or bowlers, was unconventional, but hardly threatening. The upper-middleclass Forsytes, however, in John Galsworthy's Forsyte Saga, worry about June Forsyte's fiancé, architect Philip Bosinney. He pays a duty call on her aunts 'in a soft grey hat-not even a new one-a dusty thing with a shapeless crown. "So extraordinary, my dear, so odd!" Aunt Hester had tried to shoo it off a chair, taking it for a strange disreputable cat.'2

While etiquette manuals outlined its codified rules, novels and autobiographies record the lived experience of hat-wearing as well as the adventures of those who break the rules. Fictional writing and memoirs are closer to what Raymond Williams

ISSN 1837-8692

Cultural Studies Review 2016. ( 2016 Clair Hughes. This is an Open Access article distributed under the terms of the Creative Commons Attribution 4.0 Unported (CC BY 4.0) License

(https://creativecommons.org/licenses/by/4.0/), allowing third parties to copy and redistribute the material in any medium or format and to remix, transform, and build upon the material for any purpose, even commercially, provided the original work is properly cited and states its license. 
refers to as 'structures of feeling'; that is, 'meanings and values as they are actively lived and felt'. As Williams suggests, the relation between these structures of feeling and what we find in the 'formal and systematic' rule-books is 'in practice variable'. ${ }^{3}$ We constantly question our own and each other's assumptions about the rules and their implications. The Forsytes, 'seeking the significant trifle which embodies the whole,' Galsworthy explains, 'fastened by intuition on this hat ... each had asked "Come now, should I have paid that visit in that hat" and each had answered "No!"'4

Hats as the Forsytes once understood them are no longer part of a generally accepted code: we no longer wear hats as a matter of course, and their former importance is difficult to appreciate. But the fact that they were once so central to daily life makes these 'significant trifles', a key to the 'whole', a way into the life of the past. In this article I therefore draw on written and visual material, beginning around 1800 (the period in which hats burgeoned in size and significance) but focusing on the last half of the nineteenth and early twentieth centuries, the heyday of the hat-and of the Forsytes. Commentators usually agree that decline set in around 1965 when hairstyles trumped hats in importance, but in fact hats were already losing ground in the 1930s-the point at which The Forsyte Saga concludes. The Forsytes and their anxieties about headgear then form a frame for my narrative.

Manners, morals and codes of conduct, Clive Aslet observes, have been 'privatised' and modern man 'has never been more on his own'.5 Contradictions occur in this process, since when everyone wants to show individuality there is a tendency for everyone to use much the same things to display that individuality. As an expression of difference baseball caps don't really work. Traditions survive in some contexts: hats are still worn for weddings, race meetings and contacts with royalty, but otherwise anything or nothing goes. Occupying a dramatic, isolated position among items of dress, the hat was once associated with a unique code of conduct: to wear one indicated superiority, removing it, a sign of deference. The French still salute success with the exclamation 'Chapeau!', doffing an imaginary hat.

For the Forsytes, members of the expanding middle classes of nineteenthcentury Europe, dress was the clearest sign of shifts in the social order; change and improvement was their credo, but also a cause of anxiety. The Realist novel, developing in parallel with this class-who formed its main readership-scrutinised conduct and appearance. Hats therefore punctuate novels, signalling compliance 
with custom and fashion, but more often-because it was more interesting-noncompliance: the parameters of proper headgear were defined by the improper. Because of its association with status and respect this hat-etiquette was an especially male concern. The ephemeral nature of female headgear made rules difficult to apply and for much of the earlier period female headgear was a question of caps and hoods. But if, as a man, you wear the wrong thing, 'you will probably do the wrong thing,' a manual of 1910 ruled, 'and be the wrong thing'. ${ }^{6}$ Ending around 1930, The Forsyte Saga traces forty years in a family of English yeoman stock who made the classic nineteenth-century move into a city-based merchant and professional class. The class-conscious Forsytes resist or respond to social shifts, fastening on hats as signals of change. Among the Forsytes, Bosinney begins wrongly, behaves badly and ends tragically. And he would have known the code: advice manuals published from the 1830s onwards guided hat-conduct.

\section{-TOP HATS}

'There are really two hat-tales to recount,' Michael Carter says in his essay on hats, 'one for men and one for women.'7 Male etiquette focuses on the hat's removal, female etiquette on its retention. Women are largely concerned with style and taste, men with the type of hat and its condition, as well as the where, when and how it is worn. Informal and scruffy, Bosinney's hat, for calling on Forsyte aunts in the London season, is wrong; he should have worn a silk top hat. In London of the 1870s, journalist George Sala thought a soft hat 'all very well at the seaside ... But "in society", in the streets of cities and in paying visits to those whom we hold in respect we can do no better than to adhere to the "stovepipe" of the best silk velvet nap.'8 Bosinney's gaffe might be explained by poverty, eccentricity—or indifference? June, when asked, believes he is indifferent. The idea is met with outrage: 'A man not know what he had on? No, no! ... He was an architect ... [but they] knew two architects who would never have worn such a hat upon a call of ceremony in the London season. Dangerous-ah, dangerous!'9

Two styles dominated nineteenth-century male hats: the top hat and the bowler. Straw hats were summer-wear and at the end of the century two new styles, the Homburg and trilby, were added. The cloth cap, originally indicating low status, moved up to become sports wear and, in the early twentieth century, a gesture to 
radicalism. For most of the nineteenth century, however, the top hat was de rigueur. An advice manual has a required list of 'morning and evening dress [top] hats-felt, silk and beaver', inspired doubtless by the author's trade as gentleman's outfitter. ${ }^{10}$ However, 'when a gilded youth set up as a man of fashion', the hatter, Fred Willis, says in his memoirs, 'he had the whole outfit and it was part of his education to know when, where and how to wear them ... There was a hat for every occasion and season. To go hatless through the streets was to relinquish all claim to sanity.'11

Top hats might all look alike, Willis says "but we had thirty shapes in my firm ... A young man about town would far rather spend a night in Vine Street police station than be seen walking down Piccadilly wearing last season's topper.'12 Such young men were doubtless convinced, like the character in a P.G. Wodehouse novel of the 1920 s, that 'where girls are concerned, nothing brings home the gravy like a wellfitting topper'.13 George Sala hardly recognised 'wideawakes, porkpies and what the Americans call "soft hats". A real hat-a hat of authority-should be stiff, cylindrical raven black, or milky white, and shiny.'14 At the introduction of the topper in 1790 cocked hats became 'old hat'. When silk replaced beaver as fabric it became lighter; but defects were quickly visible on its glossy surface, increasing anxiety and comment. When the silk hat was adopted mid-century by Prince Albert its status was assured. Fashion, a British periodical of 1900 for men, offered rules. Weddings, afternoon calls and receptions demanded a tall silk hat; for business and morning wear, a bowler with a lounge suit, or a silk hat with a morning coat; afternoon tea and church required a tall silk; for balls, formal dinners or the theatre, a silk or 'gibus' hat. The gibus was a top hat invented in France by M. Gibus that with a flick of the wrist collapsed into a flat oval to be stored under a theatre seat.

Bosinney's omission was ill judged but not fatal. For James Hood, however, in George Gissing's novel of 1888, A Life's Morning, the loss of his hat out of a train window is fatal. He belongs to a new class of clerks and salesmen, who, required to be always professionally dressed, were often forced into extravagance. He is on his way to a business meeting on behalf of Dagworthy, his employer, and knows 'it was impossible ... to present himself hatless at the office of Legge Brothers'. ${ }^{15} \mathrm{He}$ buys a cheap hat with his employer's money, believing all can be explained. But Dagworthy ruthlessly sacks him, precipitating Hood's suicide. In Dorothy Whipple's novel High Wages, set in 1913, her shop-girl heroine, Jane, also loses a hat, blown off into the 
street. The loss is not fatal, as a young man rescues it and love blossoms. For a man to lose his hat is serious, for a girl it may be sweetly dizzy.

-CONDITION

Recalling his ancestral acres in Dorset at the start of Galsworthy's trilogy in the 1870s, James Forsyte, who resides in London's smart Park Lane, concludes the Forsytes have done well. James wears a 'high hat ... the speckless gloss updated by careful superintendence'-a butler's daily duty. James's older brother, Jolyon, retains the beaver version, 'an excessively large hat' which he removes in hot weather as 'the great clumsy thing heated his forehead'.16 Mr Turveydrop in Charles Dickens's Bleak House of 1855 also keeps his felt topper: 'a hat of great size and weight, shelving downwards from crown to brim'.17 The detail in Galsworthy is a sympathetic reflection of Old Jolyon's conservatism; in Dickens it underlines Turveydrop's obesity and indolence. The new glossy top hat then embodies modernity and success. With fragile surfaces and seasonal variations of curl, brim and height, top hats were not only expensive but, if they were to continue to display superiority, high maintenance.

'A man is known by the condition in which he keeps his hat;' says The Hatter's Gazette, '[if] in an undeniable state of dilapidation, what salve can be applied to the wounded spirit?'18 Sherlock Holmes, examining a bowler at the start of 'The Blue Carbuncle' of 1892, deduces that its owner is a sedentary, middle-aged intellectual, fallen on hard times, whose wife no longer loves him. And his house is without gas. The hat is out-of-date and badly brushed (unloving wife), but good quality and large (big brain); it contains grey hairs and indoor dust, signs of sedentary middle age. And gas? The hat bears five tallow stains. In fact its owner, though corresponding in every sad detail to Holmes's description, is innocent. But alone, in a frock coat and a Scotch bonnet-'fitted neither to my years nor my gravity'- he is happy to see his bowler again, salve to a wounded spirit.19 Anxiety about a hat's condition is endemic: the Forsytes have butlers to maintain standards, others have to look out for themselves. 'Don't you go treading on my hat, young woman. You brush your skirts against it and you take a shillin' off its value, ${ }^{20}$ grumbles an elderly gent in $\mathrm{H}$. G. Wells's 1910 novel, The History of Mr Polly. 
-ANGLES

It is not the beauty of the hat, Robert Lloyd says, or the want of it that matters: 'the grand point is ... the position which it is made to assume on the head'. ${ }^{21}$ 'Cock your hat!' Frank Sinatra advised: 'Angles are attitudes.' Tilted to the side a hat could look rowdy or impertinent; tilted back, leisurely; but tilted too far looked tipsy. Lloyd suggests right, left and forward tilts according to different moods: thrusting the hat down on the head over the ears is bad, but worst is 'sticking the hat on the back of the head', producing 'slipshod' and 'grotesque' effects. ${ }^{22}$ Ann Veronica, H.G. Wells's feminist heroine of 1909, in a London street on her own, is addressed in a wheedling voice' by an apparently respectable man wearing 'a silk hat a little tilted'. ${ }^{23}$ She is puzzled, but the reader scents danger. A tilt like Sinatra's telegraphs cheery defiance. But as Henri Bergson the French philosopher noted: 'You may laugh at a hat, but what you are making fun of ... is not the piece of felt or straw but the shape that men have given it-the human caprice whose mould it has assumed.'24 Sports headgear is particularly prone to comedy; a topper can look dashing on a cricketer of 1850, but not when he runs and it falls off, as it certainly must.

\section{-OLD OR NEW}

How did toppers become so widespread? Willis explains that there were those like Charlie Wallop, who relieved West End hatters of discards. Charlie had been a hatter, his wife a trimmer, and by renovating discards they made a good living out of 'perfectly sound, good quality hats ... sold in pubs to cabmen, busmen and such', and so on, down the line. ${ }^{25}$ Henry Mayhew's illustrated account of 1860s London features street vendors, old-clothes men and vagrants in battered toppers-vestiges of respectability.

Willis emphasises that a gentleman's hat, though impeccable, should not be noticeably so: 'it would have been bad in the eyes of men of quality to have anything about them that was obviously new. Gentlemen had their hair cut every day so it never looked newly cut. 'If you will allow me to say so, sir,' remarks Willis to a client, 'you can take a smart hat. Smart, mind you, without looking smart ...' 'Good Lord! I don't want anything that looks smart!' 'Quite so, m'lord'.26 A century later, contemporary London milliner Stephen Jones believes 'a man's hat shouldn't look box-fresh and shiny ... stick it in the dog's basket if you must'. ${ }^{27}$ 
'Tedium in fashion,' says dress historian Anne Hollander, 'is much more unbearable than any sort of physical discomfort', and by the late nineteenth century the top hat had become tedious. ${ }^{28}$ In mid Forsyte Saga, Young Jolyon wears a 'grey top hat instead of his usual soft one' for the Eton and Harrow match 'to save his son's feelings, for a black top hat he could not stomach'.29 The hat's ability to command respect was fading. When Soames visits a newspaper office demanding to see the editor, 'after a moment's inspection of his top hat he was taken down a corridor and deposited in a small room'-where he waits a very long time. By the end of the trilogy toppers were no longer everyday wear: 'The shade from the plane tree fell on [Soames'] neat Homburg hat; he had given up top hats-it was no use attracting attention to wealth these days.' 30

-THE POLITICAL HOMBURG

It was Edward VII as Prince of Wales who introduced Homburgs, bringing them from Germany as presents and wearing one himself on informal occasions. Unlike the top hat and bowler it was a soft felt, derived from the Alpine hat. With its dented crown and curled brim it had a distinctive outline; it was not so soft you could wear it anyhow like 'slouch' hats that habitually lapsed into shapelessness; Edward's example made it acceptable in town.

As is clear from The Forsyte Saga, much of what had been unacceptable before World War I became acceptable after. Rigidity, whether of manners, morals or hats, gave way to greater laxity. Shortage of shellac during the war meant that quotas of toppers and bowlers could not be met. ${ }^{31}$ The bowler replaced the city topper and the Homburg was endorsed for less formal wear, growing stiffer as it gained status. In 1930s Britain it arrived socially when Winston Churchill alternated it with his famous bowler; his successor Anthony Eden wore it so often that it became known as 'the Anthony Eden'. Neither was making a political point, though Socialist leader Keir Hardie's cloth cap, when he entered Parliament in 1892, was for Willis, a 'bomb'. ${ }^{32}$ Hats were not worn inside Parliament but, until after World War II, members raising a point of order had to be 'seated and covered'; that is, hatted. In a painting of the House of Commons of 1833, after the Reform Act, some members are in toppers (there is even a green one) perhaps prompting the Duke of Wellington to say he had never seen so many 'shocking bad hats'. ${ }^{33}$ 
In America the Homburg became a political hot potato at the 1953 inauguration of President Eisenhower where etiquette decreed silk toppers. Having once sold hats, the incumbent President Truman felt strongly about them and wore a silk at his own inauguration. After all, Time magazine said, it was the nearest thing the United States of America had to a coronation. But Eisenhower was dismayed at the prospect: 'He'd be damned if he was going to parade down Pennsylvania Avenue in a top hat.' Some congressmen demurred, but Eisenhower held out: 'They are going to be the silk hat boys. And we will wear dark Homburgs.' Truman fumed: 'The president should wear the most formal of formal clothes.'34 Eisenhower was Republican, Truman a Democrat, but as so often, radical change is best undertaken by conservatives. If this hat spat seems trifling, the US hat manufacturer, Mortimer Loeb, saw it as a mortal blow.

Responsibility for the hat's general demise as part of modern male apparel has been attributed to President Kennedy, whose boyish quiff was never subdued by a hat, but decline had already begun. Eisenhower, a Kansas boy, might have been rejecting East Coast elitism, going hatless was also a question of comfort and personal choice. Kennedy did in fact wear a top hat in 1960 to his inauguration, but never again. Semi-royal, Kennedy really had no need to show conformity with etiquette. In privileging autonomy, comfort and personal appearance over recognised social signifiers these two presidents were entering-all unconsciously-a new era, identified by Gilles Lipovetsky, French philosopher and sociologist, as one where 'we no longer love things ... for the social status they confer, but for the services they render, for the pleasure they provide'. ${ }^{35}$

Kennedy did not even wear the Homburg's successor, the trilby. Little distinguishes the trilby from the fedora: both were soft felts with dented crowns, the fedora wider-brimmed with more of a 'snap'. ${ }^{36}$ Often pale in colour, the fedora was more popular in America and Europe than in Britain, and adopted by adventurers (Indiana Jones) and bohemians as romantic but more respectable than the 'slouch'. Nowadays, 'in an era of eclectic dress', American hat historian Debbie Henderson says, 'a fedora can symbolize a range of social and occupational levels. If the bowler has gone the way of the entertainer, the fedora has been grabbed up by the person in the know ... now the most dressy style.'37 In Britain, the trilby became the universal business hat; the bowler's territory narrowed to the City and St James's. 
'No man who aspired to be a member of respectable society would have dreamed of walking abroad after May in the regulation bowler,' Willis says. 'Straw boaters then appeared as spontaneously as wild roses on the hedgerows and the sombre bowler was carefully laid away until chill October.'38 So when Bram Stoker's Count Dracula walks through London in November, all in black, in a straw hat that 'suits not him or the time', something is up. ${ }^{39}$ 'A straw hat cannot be worn with a black coat of any kind', Mrs Humphry ruled; furthermore, it was leisure not city wear. ${ }^{40}$ Dracula is not respectable.

Straw hats have always been part of the working wardrobe of the countryside but they also surface as fashion items: 'bowlers, boaters and the rest are constantly appearing Above because they are permanently in use Below' (socially rather than physically speaking). ${ }^{41}$ In Britain the straw boater was originally naval headgear, cooler in the Empire's more torrid zones than the traditional hat of varnished leather. The Cunningtons note the first mention of a 'Nautical Hat' in 1849 and by the next decade it had become a fashion item: 'flat crowned and narrow-brimmed with ribbon bands which dangled behind'. ${ }^{42}$ Available at all prices, the straw sailor hat was an obvious accessory to light clothes and quickly became summer wear across class boundaries, sex and age. Schoolboys and clergymen took to them, and by the end of the century, inspired by the Princess of Wales, women were trimming boaters and skewering them onto their coiffures with hatpins.

Old Jolyon Forsyte found his topper unbearable in the hot summers of the late Victorian period and men started to replace tall hats with light felts, boaters and panamas. The Hatter's Gazette of 1894 reported that 'the weather was so hot ... that at last common sense triumphed and there was a sudden epidemic of straw hats'. Ladies have taken to plaiting, the Gazette continues, and 'the Queen herself is plaiting straw for hats for her sons and nephews'.43

The Cunningtons call the straw hat the most significant headgear of the 1890s, 'destroying an age-old symbol of social rank, for this new kind of headgear had no class distinctions'.44 Distinctions were invented, however, and like the topper, condition, style and tilt became important. 'The real old school', Willis says, 'despised the creamy whiteness of the normal boater and wore only a straw hat the colour of old parchment ... it stamped the wearer as out of the "top drawer".'45 
Society was not 'in town' during summer, says an advice manual; so 'if you happen to be in town, you can wear a light thin lounge suit and a straw hat'.46 Upper-class Matthew Peel-Swynnerton, in Arnold Bennett's Old Wives' Tale of 1911, leaps out of a cab in summertime London, 'holding his straw hat on his head' to greet 'another straw hatted figure', Cyril Povey, an upwardly mobile provincial. The cabman waits with 'no apprehension of miserly and ungentlemanly conduct by his fare. He knew the language of the tilt of a straw hat.' 47 But he is wrong: Matthew is broke, Cyril pays.

By 1900, when Bennett's novel ends, the English gentleman's sartorial image was no longer a badge of social stability, but was, as Christopher Breward in The Hidden Consumer argues, 'a contested site for the playing out of struggles for preeminence between waning and rising social groups'.48 Made in Ecuador but exported from Panama, panamas had been popular during the California gold rush, but they took off globally when Napoleon III popularised them after the Paris Exhibition of 1855. The best hats were so finely woven that the fabric looked and felt like silkand they were expensive. Edward VII spent $£ 90$ in Bond Street on his: 'One hundred pounds for a Panama,' the Strand Magazine exclaimed, 'enough to take a three month's holiday, enough to keep your son at college, enough to buy a small farm.'49

Galsworthy's contemporary, H.G. Wells, launches his plebeian hero, Kipps, into Edwardian society with an inheritance and makes him a circus turn, a carthorse among show-jumpers facing the hurdles of etiquette. Like Galsworthy, Wells focuses on that significant trifle, the hat, to trace Kipps's career, whose ambition is to be if not a gentleman, at least mistakably like one'. He spots a panama 'of the most abandoned desperate cut' and wonders where to buy it: soon, sporting 'a Panama hat and a silver-mounted stick [he feels] extraordinarily different'.50

Kipps is taken up by middle-class Helen and worries about his appearance: 'Luckily she had not seen the Panama hat. He knew he had the brim turned up wrong.' He looks better without it at a boating party, but then awful scenes with top hats ensue, during which Helen remarks crushingly, "'a real gentleman looks right without looking as though he had tried to be right". [Kipps] in his heart was kicking his silk hat about the room.' Etiquette here is specifically class-related. The point of upper class 'distinction', as French sociologist Pierre Bourdieu showed in his book of 1979, Distinction, is that you're supposed to know it all without being taught: Kipps 
may now have money but being lower class by birth and upbringing he has no 'cultural capital' to draw on. The final straw-literally-for Kipps is a party to which he wears a frock coat, 'a Panama hat of romantic shape, grey gloves but for relaxation brown button boots', to convey an air of 'seaside laxity'.51 The occasion is a fiasco, exacerbated for Kipps by seeing his first love, Anne, employed as waitress. He abandons Manners and Rules of Good Society, drops Helen and rediscovers Anne; and, as he falls into her arms, "his fashionable and expensive "gibus" fell, rolled and lay neglected on the floor'; hats then disappear from the novel. Wells restores the couple to their proper station in life: keeping shop. ${ }^{52}$

\section{- HAT HONOUR}

Little separates Wells's image of Kipps from Chaplin's clowns. Bosinney's hat was wrong, but not comic. If Kipps fails to match hat to occasion, there was also the thorny question of 'hat honour': when and where to raise your hat, to whom you raise it, what you do with it once off. By the eighteenth century wigs had altered the manner of doffing the hat: previously it had been raised and then placed against the thigh, crown outwards, but with wigs, the inside could be shown without fear of revealing greasy linings. When the plumed cavalier hat shrank to a neat tricorne it was not necessary to actually wear the hat, carrying it was sufficient and it eventually evolved into the flat, purely ceremonial 'chapeau bras', still in use. An illustrated manual of the 1730s, dealing with dance and deportment, shows ways to raise the hat and bow, complex manoeuvres allied to dance. A later advice book recalls those times when 'lifting the hat used once to be a most elaborate performance, the result of much study and the exponent of much grace'. The modern man, he sniffs 'gets through it in a couple of seconds'. ${ }^{53}$

Worries about tipping hats to ladies replaced tipping them to superiors. After Helen snubs his efforts at gentility, Kipps becomes so nervous he tips his hat to ladies everywhere. Etiquette claimed to aid 'the smooth running of society', but applying rules was tricky: 'A gentleman should not raise his hat to a lady until she has accorded him [a bow]. When a gentleman returns the bow of a lady with whom he is slightly acquainted he should do so ... very slightly raising his hat from his head.' If she is a friend, 'he should raise his hat with more freedom of action'. If he meets a gentleman friend walking with a lady with whom he is unacquainted, 'he 
should not raise his hat, but nod to his friend'. Gentlemen 'do not raise their hats in recognition of each other, but simply nod'.54 Mrs Humphry in Manners For Men, however, insists 'the hat must be raised even in saluting a familiar friend if a) he is accompanied by a lady, and b) when one is oneself accompanied by a lady'.55

Hat honour in an American guide seems especially taxing: upon meeting social inferiors, for example, one should, 'without bowing or touching the hat, salute in a kindly voice'. When meeting ladies and gentlemen together 'one should lift the hat ... bowing first to the lady' and then include the gentleman in a 'sweeping motion ... as you part, again take your hat off'; if stopped by a lady-friend, 'allow her to terminate the interview and raise your hat quite off as you take leave'. On the other hand, if 'a stranger lady addresses you ... touch your hat ceremoniously with some phrase of respect'.56 In Henry James's novel The American, Christopher Newman exploits convention when the aristocratic Bellegardes cut him in a Paris park: 'Newman stepped in front of them ... he lifted his hat slightly': fiercely punctilious, they are obliged to stop and hear him out. 57

'Ah, the hat-raising!' marvels Willis, 'we had to make toppers with reinforced brims to bear the strain for gentlemen in Mayfair.'58 Willis himself had a fine hatraising moment. Walking across Hyde Park one morning in 1901, he noticed an open carriage: 'my eyes fell on the occupant and I recognized the King ... I clumsily raised my hat. He instantly acknowledged my salute by raising his.' ${ }^{59}$ Even Kipps succeeds in this gesture: 'he hesitated for a moment and suddenly did great things with his hat. The hat! The wonderful hat of our civilization!'60 Still wonderful, still civilised, the Irish Times of April, 2014, reported that Windsor town crier's main task on the visit of the Irish President was to remind councillors 'to take their hats off when Mr. and Mrs. Higgins, the Queen and Prince Philip pass by in a horse-drawn carriage'.

Courtesy calls meant entering the home, and what to do with hats indoors opened up another Pandora's box of potential faux pas. The Princess Casamassima is Henry James's most class-conscious novel and accordingly rich in headgear. Prince Casamassima, wondering whether those processing in and out of his estranged wife's London house are her lovers or tradesmen, is told that the current young man, Hyacinth Robinson, is a bookbinder. He protests, 'why then does she have him in her drawing room-announced like an ambassador, carrying a hat in his hand like 
mine?'61 Hyacinth has, however, been brought up in working-class London; a class, Willis says, that were sticklers for etiquette.

James does not mock Hyacinth with conduct manuals. Hyacinth knows that a gentleman 'should take his hat and stick in his hand with him into the drawing room and hold them until he has greeted the mistress of the house. He should either place them on a chair or table or hold them in his hand according to whether he feels at ease or the reverse until he takes his leave.' 62 Mrs Humphry elaborates: 'The reason for carrying the hat ... is based on the supposition that the masculine caller feels himself privileged ... ready to leave should he not find his presence acceptable.'63 Hyacinth's innate grace confuses the Prince, but the Princess is not pleased: 'you've nothing of the people about you today,' she complains. To suggest that, invited as a guest, he might present himself in working mode is insulting: 'you do regard me as a curious animal', he says. ${ }^{64}$ She wants him to act the proletarian to gratify her image as class rebel and annoy the Prince, who reasonably wonders if the bookbinder has designs on his status, his silver or his wife.

One might expect the blacksmith Joe Gargery, in Charles Dickens's Great Expectations, to be as amusing with hats as Kipps; dress in Dickens's novels is after all often used as a comic, identifying quirk. Joe is in London to see Pip, who is being 'improved', and has neglected his home in the country with his sister and her husband, Joe. "I'm glad to see you, Joe", Pip says, "give me your hat". But Joe, taking it up carefully with both hands ... wouldn't hear of parting with that piece of property' and looks for somewhere to put it. Increasingly irritated, Pip watches the hat's progress, toppling off every resting-place: 'Joe rushing at it and catching it neatly as it dropped; merely stopping it midway, beating it up and humouring it in various parts of the room.' But Dickens suddenly pulls the rug from under our feet. Joe takes his hat and goes: "'you and me is not two figures to be together in London ... I'm wrong in these clothes."'65 In a sobering volte-face, Pip realises that any breach of courtesy is his: he has reacted with a snobbery in which the amused reader has been complicit.

-ETIQuetTe for LAdies

Indoors or out, and less indicative of status, hat etiquette for women was not as fraught as that for men. In the eighteenth century women wore caps, as 'undress' 
(informal), or as 'dress' (formal), or as outdoor wear under hats. Elite women seem to have felt freer to appear bare-headed. During the nineteenth century caps became wear for married or mature women and then for servants and the elderly. There were caps for morning that should be plain, and lacier, beribboned affairs for receiving in the afternoon. For making calls a bonnet was required and later, a hat. But it was difficult for manuals to lay down rules when styles changed so fast; sometimes a current mode was singled out for approval or, more often, disapproval.

From the late eighteenth century women played a larger part in the public scene than they once had. There were therefore places and occasions when their appearance, and especially their headgear, became subject to rules, spoken or understood. But until the 1960s one principle seemed inviolate: no woman went out of the home without a hat. Gwen Raverat, recalling a 1890s childhood in Period Piece, hated hats. 'We should catch cold,' the grown-ups told her, 'or get sunstroke if we went bareheaded. But the real reason was that it was proper.'66

-SUNDAY BEst

Hats were especially 'proper' on occasions associated with church: Sunday services, weddings and funerals. Raverat recalls two girls on a Sunday morning with 'beribboned, top-heavy hats stuck on the top of hair they had spent so long in frizzling and puffing out'.67 Church was the site of much hat activity and debate, but being neither a private nor public space, only sui generis, rules were initially uncertain. The prohibition on male hats in church does not go back far; both sexes wore hats in church until the seventeenth century, acting as though it were a public space. The religious tolerance of post-Civil War Britain did not extend to hats however and St Paul's strictures were invoked: the heads of men in church should be uncovered, those of women covered in acknowledgement of the Lord's Day. Men removed hats at the door, and in the nineteenth century were asked not to leave them in the font. Hat-pegs can be found on some church walls and Amish meetinghouses in America, but generally men were expected to organise headgear as best they could.

Dickens loved Sundays where 'the fine bonnet of the working-man's wife or the feather bedizened hat of his child [showed] no inconsiderable evidence of good feeling'. ${ }^{68}$ Church was a place to see and be seen, a weekly opportunity for display. 
Fred Willis recalls 'a dreadful predilection for black and sombre colours', but Thomas Hardy's country girl likes 'a nice flare-up about my head o' Sundays'.69 Hardy and Raverat were writing at a time when hats were especially large and smothered in flora, fauna and feathers, miniature natural habitats. ${ }^{70}$ But in the eyes of one's neighbours there was a line to be drawn between respect and fashion in church. Dick, betrothed to Fancy Day in Hardy's Under the Greenwood Tree of 1872, is uneasy when he sees her feathered hat on a Sunday when he cannot attend: 'You've never dressed so charmingly before,' he says. Others are more blunt: “'disgraceful! Curls and a hat and feather! ... A bonnet for church always!" said sober matrons.'71 The hat, a barometer of its owner's mood, suggests that Fancy has found more interesting fish to fry than Dick.

-MOURNING

In England until the late nineteenth century it was the custom at funeral services for the clergyman's hat, swathed in black silk, to be hung behind the pulpit where it remained until the sermon had ended. Undertakers still wear black silk top hats at funerals, even when an undertaker-as now sometimes happens-is a woman. The black top hat persisted as correct mourning into the twentieth century. Nineteenthcentury American mourning was more oppressive than British; The Ladies' Home Journal in 1891 decreed that widows be shrouded in a floor-length veil for three months, rising to the waist for the next six. British Manners and Rules of Good Society of 1892, while allowing that etiquette was now less strict, advises two years mourning for a widow: 'the widow's cap should be worn for a year and a day'.72 George Eliot, in her novel Middlemarch set in the 1830s, but published in the 1870s when rules were becoming relaxed, describes Dorothea Casaubon, who, freed by the death of her husband from an unhappy marriage, swathes herself in excessive black. Her grim cap, so inappropriate to the summer season and so inauthentic, irritates her sister Celia, who removes it. When Dorothea then has a sharp exchange with a visitor, Celia slyly notes, 'taking your cap off made you more like yourself in more ways than one'. ${ }^{73}$ 
-WedDINGS

Hats are now no longer obligatory outdoor wear, with certain styles and materials being considered appropriate for certain occasions or seasons: if you do choose to wear a hat now, you are on your own, as Clive Aslet says; mistakes will be of taste not breaches of convention. But weddings still awake a need in many breasts across class, age or country, for something special on the head, something reflecting the important, ritualistic nature of the occasion. This hat-urge began after the Marriage Act of 1753 when weddings in England had to be performed in church before witnesses: church custom demanded headgear for both sexes, male hats to be removed at the door. Weddings used to take place early in the day, bonnets, or later hats, were therefore appropriate for those attending. 'He knew how far he could go with a woman and yet keep clear of having to meet her in church without her bonnet', Thomas Hardy says in 1876 of one of his cannier peasants: a bride would of course be the one female in church without a bonnet. ${ }^{74}$ According to Modern Etiquette of 1890 wreath and veil were indispensable; for quiet weddings, however, a bonnet and veil were correct. In William Thackeray's Vanity Fair, Amelia Sedley, fallen on hard times, is married in 'a straw bonnet with a pink ribbon; over the bonnet she had a veil of white Chantilly lace'.75 Amelia, however, is allowed a white bonnet when she finally falls into Dobbin's arms-in the street, not church, so etiquette is maintained. The focus of weddings has now shifted from church service to evening party, top hats are disappearing, though still seen at society weddings; fascinators are replacing hats for young and old (easier to dance in), though elaborate confections can still be seen-'huge muffs of horror' as Nancy Mitford called them-on all sorts and conditions of females whether in France, Britain or America. ${ }^{76}$

-HATS OR BONNETS

There was some jostling between hats and bonnets in the second half of the nineteenth century. Fancy Day's feathers are excessive, but it is the fact she is wearing a hat not a bonnet in church that shocks. Though the terms 'hat' and 'bonnet' are often interchangeable, the bonnet concealed much of the hair and face and tied under the chin. In Henry James's Roderick Hudson, Mme Grandoni, the heroine's chaperone, calls on Roderick's mother: 'She is very old to wear a hat', Mrs 
Hudson remarks, 'I should never dare to wear a hat.'77 In the 1870 s, the period of James's novel, hats had almost replaced bonnets, but Mrs Hudson, a conservative New Englander, feels bonnets to be proper for those of a certain age.

-Place And ocCAsion

Except for tea parties or brief courtesy calls, where it would be difficult to take them off and still trickier to put them on again, women did not wear hats indoors. The growth of hotels, restaurants, concert and exhibition halls in the nineteenth century, however, blurred the lines between indoors and out, complicating etiquette. The paintings of Walter Sickert or Toulouse Lautrec of the period make it clear that in France and Britain at least hats were worn by both sexes in cafés, bars and music halls. However, such louche associations meant that in the 1930s, when milliner Aage Thaarup was hoping to design hats for dining out, a maître-d'hôtel told him that after seven o'clock only prostitutes wore hats.

Advice about how to wear hats in hotels was helpful and Mrs Sherwood commended 'the etiquette of raising the hat on the staircases and in the halls of a hotel as gentlemen pass ladies', but in hotel parlours she believes hats were seldom worn. ${ }^{78}$ For garden parties hats were correct for host and guests; boat-decks counted as 'outdoors', as did picture galleries. Thomas Hardy's upwardly mobile heroine, Ethelberta, takes her artisan brothers to the annual Royal Academy Exhibition in 1870s London. Conscious of exalted company, the brothers present a 'too reverential bearing towards the well-dressed crowd ... walking with their hats in their hands with the contrite bearing of meek people'.79

For the theatre a top hat was obligatory. But once inside-where to put it? For gentlemen the collapsible 'gibus' top hat solved the problem and was stowed under the seat; for women 'either a bonnet or hat may be worn', but might be removed 'in consideration of those who sit behind'. ${ }^{80}$ This became an issue with the gigantic hats of the 1890s. Jewelled hair ornaments then became popular and James's Princess Casamassima in her theatre box satisfies etiquette with 'two or three diamond stars'. Not an option open to all, but flowers could lend a similar sense of occasion. 
-THE RACECOURSE

'The Derby, Ascot, Goodwood and the Eton and Harrow Match', Willis remembers, 'what did all this mean to me? More hats to iron, more smashed toppers to repair', he says happily. Old Boys and pupils at the Eton and Harrow Match expected to have their hats smashed but for the ladies (even in 1969) 'your best summer dress' was required, 'with a hat'-unmolested one hopes. ${ }^{81}$ Jeans may now be worn to the opera but race meetings for some reason still call for hats and attract publicity for the most striking confections. Etiquette at first seems to have been an agreement to dress in one's 'best'. William Frith's painting of 1858, Derby Day, is a panorama of Victorian society and contains all the headgear of the period. Top hats give clues to status and character in a composition packed with narrative incident; bonnets predominate, from modest to dubiously extravagant.

A key scene in George Moore's novel of 1894, Esther Waters, takes place at Epsom, and owes much to Frith's painting. Having known little but poverty, Esther is for once solvent and has bought 'a white hat tastefully trimmed with lilac and white lace' for Derby Day. Her husband William was 'very wonderful in his green necktie, yellow flowers and white hat'. They set off for the novel's one brief, bright holiday moment when hats and pleasure were unconstrained, in an omnibus 'filled with fat girls in pink dresses and yellow hats'. ${ }^{82}$ Nowadays etiquette requires 'smart casual dress' in the stands; in the Queen's Stand and Grandstand, 'ladies are asked to wear a fascinator or hat' and gentlemen, 'grey morning dress with a top hat'.

Royal Ascot, as its name suggests, is another matter. Founded by Queen Anne in 1711, it has become a fashion focus of the London season. The most prestigious race is the Gold Cup, when hats as much as horses compete. A 1969 guide to 'modern manners' suggests that the best hat should be kept for this: 'Well-known Ascot goers have been seen to wear the same dress twice, but they will still wear different hats.' ${ }^{83}$ Access to the Royal Enclosure is restricted and dress codes enforced: grey top hats for men, and a day dress and hat for women. Fascinators (much despised by some milliners as apologies for hats) have recently been banned. But hats, sublime or ridiculous, flourish, and have so focused media attention that horses become of secondary interest. Harry Graham's comic advice manual of 1912 recounts hat-panic when Graham and his friends, on their rowdy way to Ascot, lose their toppers: 'it was obviously impossible for any self-respecting person to walk about the Enclosure 
in a frock coat surmounted by a straw hat!' Officials were rude, spectators jeered and their conduct was attributed 'to a sudden conversion to Socialism'. 84

If President Kennedy was said to have dealt male hats a mortal blow in 1960, Jean Shrimpton's appearance in 1965 at the Melbourne Cup carnival marked a crisis for fashion hats and the passing of a generation. Hats had been in decline for some time, but it took these two celebrities to dramatise the fact. Proving that less is more, Shrimpton, who had been the focus of media attention as a top model, appeared, hair blowing in the wind, hatless, gloveless, sleeveless, stockingless (it was hot) in a mini-dress against a sea of hats at Melbourne's biggest social event. She made everyone else, as dress historian Prudence Black says, look 'old and dowdy'. The Lady Mayoress fumed: 'not wearing a hat or gloves on Saturday ... [was] very bad manners'. ${ }^{85}$ She did in fact wear a hat the next day, as Kennedy did wear a hat at his inauguration, but the damage had been done. Hats did not completely disappear but their sudden obsolescence in 1965 was 'a singular chapter in the annals of Western fashion', according to the daughter of 'Tatiana', one of New York's favourite milliners of the 1950s. ${ }^{86}$ There were socioeconomic factors at work: the democratisation of socialist, postwar Britain and of the United States during and after the Kennedy years meant that the class distinctions that hats had marked were blurred, and mass-production made model hats increasingly irrelevant: exclusivity was expensive and no longer smart. The young-especially the female young, now educated and in work-acquired spending power, which they did not use on hats; hair had become more important.

Hats will always be serviceable, protective in sport and against the elements, but with hindsight it could be said that as they were being discarded as representative of a fusty pre-war order, a new era began where, as Gilles Lipovetsky argued, things were loved not for the status they conferred but for the pleasure they provided. In the world of popular music, for example, when visuals became increasingly important, hats often became part of the act. Free of status and convention hats for both sexes played with older forms, mocked them, reinvented them or moved into fantasy realms where they became desirable works of art; the hats of today's milliners are collected by museums. Kennedy, followed by Jean Shrimpton, had cleared away the rule-bound old to make place for the inventive, pleasurable new. Immigrants from other cultures were challenging tradition, and in 
Australia were forming an identity that favoured classlessness and informality. Ironically, it was the English Jean Shrimpton who had provided a turning point.

But in an effort to keep racing alive in Australia, Black explains, the young are now encouraged to see the Melbourne Cup as a festive fashion event that includes hats. Shrimpton challenged conformism: she now looks rather heroic, like Liberty Leading the People. Fashion may contravene etiquette, the 'structure of feeling' and its relation to the rules may change, but contraventions may then, in their turn, become the new fashion. So hats, having for a time disappeared, have been reborn, not as obligatory but as fun and celebratory-not only in Melbourne, but also at Ascot and Epsom. What changed for hats were attitudes; they are now worn for pleasure and effect, not for status or respect. Why go hatless to Ascot when it is an excuse for a harmless bit of dressing-up?

At the end of The Forsyte Saga, Soames goes to Ascot. His daughter Fleur gets him a grey top hat: 'they're all the go this year'. Soames is confused: “White elephant", he said "Can't think what made Fleur get me the thing".'87 Caught up in the excitement he begins to cheer despite himself; taking off his hat he looks inside it as if to discover its secret. Unloved in the first part of the Saga, Soames has grown sympathetic. Here, at the last, he forgets the past and responds to the moment. His hat is not just correct, but 'all the go'. He has worn the right thing, done the right thing and is finally not so bad. The 'significant trifle', has returned, like the Forsytes themselves: the same but changed.

-SURVIVAL

George Bernard Shaw believed acquired notions of propriety were stronger than natural instincts: a British officer could never be induced 'to walk through Bond Street in golfing cap'.88 But if etiquette was indelibly imprinted on the British psyche, then when it went, daily life could be tricky. Letters to The Times of the 1930s addressed the problem: 'I cannot keep my hat on in a bank, though I know my courtesy is often taken for eccentricity. What has the poor banker done, that he should be insulted?' And there was the question of courtesy to ladies. A solution was offered: 'I used to smile (I hope) charmingly and incline my head in ... a lingering, slightly fond manner ... the method still works.' 89 Fleur, in the final pages of the Forsyte Saga, 'smiled and the old boy cocked his hat at her. They all cocked their hats 
at her, and that was pleasant.' ${ }^{90}$ Might she have preferred 'a lingering, slightly fond manner'? She seems uncertain, but in any event she smiles. In 2011, wearing, I felt, a rather dashing Stetson, I myself was walking along Piccadilly when a gentlemanwhom I had never met-walking towards me, touched the brim of his bowler and said 'Good morning, Madam': it was pleasant and I smiled. Hat spoke to hat in an exchange of courtesies between strangers, a bright moment on a grey morning-the hat method can still work.

Claire Hughes is a graduate of The Courtauld Institute, London. She taught in institutions of higher education in the United Kingdom and Japan, finally as Professor of English and American Literature in Tokyo's International Christian University. She now lives in Ireland and has published books on British art and on the role of dress in literature.

\section{-NOTES}

${ }^{1}$ Frederick Willis, A Book of London Yesterdays, Phoenix House, London, 1960, p. 277.

2 John Galsworthy, The Forsyte Saga, vol. 1, A Man of Property, Penguin Books, London, 2001 [1906], p. 14.

${ }^{3}$ Raymond Williams, Marxism and Literature, Oxford University Press, Oxford, p. 122.

4 Ibid., p. 15.

${ }^{5}$ Clive Aslet, Anyone for England, Little, Brown, London, 1997; quoted in Henry Hitchings, Sorry! The English and their Manners, John Murray, London, 2013, p. 295.

${ }^{6}$ John Wanamaker, The Etiquette of an Englishman's Dress, New York, 1910; quoted in Brent Shannon, The Cut of his Coat, Ohio University Press, Athens, 2006, p. 148.

7 Michael Carter, Putting a Face on Things, Power Institute of Fine Arts, Sydney, 1997, p. 113.

8 George Augustus Sala, The Hats of Humanity, James Gee, Manchester, 1874, p. 60.

${ }^{9}$ Galsworthy, A Man of Property, p. 15.

10 G.P. Fox, Fashion: The Power that Influences the World, Sheldon \& Co., London, 1872, pp. 17-18. Quoted in Christopher Breward, The Hidden Consumer, Manchester University Press, Manchester, 1999, p. 44 .

11 Willis, A Book of London Yesterdays, pp. 152, 137. 
12 Ibid., p. 152.

${ }^{13}$ Quoted in Colin McDowell, The Literary Companion to Fashion, Sinclair Stevenson, London, 1995, p. 318.

${ }^{14}$ Sala, p. 16.

15 George Gissing, A Life's Morning,: IndyPublish.com, Boston, 2012 [1888], p. 135,

16 Galsworthy, A Man of Property, pp. 140, 84, 336.

17 Charles Dickens, Bleak House, London: Wordsworth Classics, 2004 [1855], p. 164.

18 The Hatter's Gazette, August 1878, p. 690.

${ }^{19}$ Conan Doyle, The Complete Illustrated Sherlock Holmes, Chancellor Press, London, 1987 [1892], p.

127.

${ }^{20}$ H.G. Wells, The History of Mr Polly, Everyman, London 1993 [1910], p. 46.

${ }^{21}$ Lloyd, p. 36.

22 Ibid., p. 37.

${ }^{23}$ H.G. Wells, Ann Veronica, Everyman, London, 1999 [1909], p. 72.

${ }^{24}$ Henri Bergson, Laughter: An Essay on the Meaning of the Comic, trans. Cloudesley Brereton and Fred Rothwell, The Macmillan Co., New York, 1914, p. 3.

25 Willis, A Book of London Yesterdays, pp. 139, 151.

${ }^{26}$ Ibid., pp. 133, 144.

27 Stephen Jones, quoted in The Telegraph, 28 May 2014, <www. telgraph.co.uk/menfashion-andstyle/10803883/Hat-tricks-how-to-look-good-in-a-hat.html>.

${ }^{28}$ Anne Hollander, Sex and Suits, Knopf, New York, 1994, p. 49.

${ }^{29}$ Galsworthy, A Man of Property, p. 410.

30 Ibid., p. 661.

${ }^{31}$ Shellac was derived from an insect found in India used to stiffen cocked hats as well as top hats and bowlers.

32 It was actually a deerstalker, perfectly acceptable for travel; Hardie had just come off the train.

33 George Hayter, The House of Commons, 1833, National Portrait Gallery, London.

34 Quoted in Neil Steinberg, Hatless Jack, Granta Books, London, 2005, pp. 73, 74.

35 Gilles Lipovetsky, The Empire of Fashion: Dressing Modern Democracy, trans. Catherine Porter, Princeton University Press, Princeton 2002 [1994], p. 146.

36 Both hats were named after theatrical heroines: Fedora by Victorien Sardou, was a hit in America in 1882, as was Trilby by George du Maurier in London in 1885.

37 Debbie Henderson, Hat Talk, Wild Goose Press, Yellow Springs, Ohio, 2002, pp. 80, 83, 86.

38 Willis, A Book of London Yesterdays, pp. 137, 138.

39 Bram Stoker, Dracula,: Penguin Classics, London, 1993 [1897], p. 408.

40 Mrs Humphry, Manners for Men, Webb \& Bower, Exeter 1979 [1897], p. 115.

${ }^{41}$ Henderson, p. 161. 
42 C. Willet and Phyllis Cunnington, Handbook of English Costume in the 19th Century,: Faber \& Faber, London, 1966, pp. 223, 252.

43 The Hatter's Gazette, September,1894, p. 479.

44 Ibid., p. 341.

45 Willis, A Book of London Yesterdays, p. 138.

46 'The Major', Clothes and the Man, Grant Richards, London, p. 192.

${ }^{47}$ Arnold Bennett, The Old Wives' Tale,: World's Classics, Oxford, 1995 [1911], p. 471.

48 Breward, p. 59.

${ }^{49}$ Quoted in <www.panamahats. co.uk/pages/History-of-Panama-Hats.html>, p. 1.

50 Wells, pp. 45, 102, 124.

51 Ibid., pp. 149, 157,173, 250, 253.

52 Ibid., p. 326.

53 Anon., Modern Etiquette,: Frederick Warne, London (c. 1890), p. 47.

${ }^{54}$ A Member of the Aristocracy, Manners and Rules of Good Society, Frederick Warne, London 1892, p. 31.

55 Humphrey, p. 17.

56 Anon., The American Gentleman's Guide to Politeness and Fashion, Daley \& Jackson, New York, 1859, pp. 130, 131.

${ }^{57}$ Henry James, The American, Penguin, London, 1991 [1876], pp. 405, 410.

58 Willis, A Book of London Yesterdays, p. 151.

59 Fred Willis, 101 Jubilee Road, Phoenix House, London, 1948, p. 21.

60 H.G. Wells, Kipps, Penguin Classics, London, 2005 [1905], p. 203.

61 Henry James, The Princess Casamassima, Augustus Kelley, Fairfield, 1976 [1888], p. 305.

62 A Member of the Aristocracy, p. 31.

63 Humphrey, pp. 122, 123.

64 James, Princess Casamassima, p. 292.

65 Charles Dickens, Great Expectations, Broadview Press, Peterborough 1998 [1862], pp. 249, 252, 254.

66 Gwen Raverat, Period Piece, Faber \& Faber, London 1954, p. 223.

67 Ibid., pp. 260, 256.

68 Charles Dickens, The Uncommercial Traveller, Chapman \& Hall, London, 1906 [1859], p. 327.

${ }^{69}$ Willis, 101 Jubilee Road, p. 70; Thomas Hardy, The Hand of Ethelberta, Everyman, London, 1998 [1876], p. 139.

70 In 1912 the export of ostrich feathers from South Africa to Britain was worth $£ 2.6$ million. See Michael Carter's chapter on nineteenth-century hats and their excesses in his book Putting a Face on Things.

71 Thomas Hardy, Under the Greenwood Tree, Penguin, London, 1998 [1872], pp. 132, 133.

72 A Member of the Aristocracy, p. 223. 
73 George Eliot, Middlemarch, Norton, New York, 2000 [1871], p. 340.

${ }^{74}$ Hardy, The Hand of Ethelberta, p. 124.

75 William Thackeray, Vanity Fair, Penguin, London, 1968 [1847], p. 260.

76 Colin McDowell, The Literary Companion to Fashion, Sinclair Stevenson, London, 1995, p. 215.

77 Henry James, Roderick Hudson, Penguin, London, 1986 [1875], p. 286.

78 Mrs John Sherwood, Manners and Social Usages, Harper Bros, New York, 1884, p. 293.

${ }^{79}$ Hardy, The Hand of Ethelberta, p. 150.

${ }^{80}$ Richard Wells, Manners, Culture and Dress of the Best American Society, King, Richardson \& Co., Springfield, MA, 1891. p. 338.

${ }^{81}$ Anne Edwards and Drusilla Beyfus, Lady Behave: A Guide to Modern Manners for the '70s, Cassell, London, 1969.

82 George Moore, Esther Waters, Walter Scott, London, 1894 [1885], pp. 254, 257, 259, 260.

83 Edwards and Beyfus, p. 290.

${ }^{84}$ Harry Graham, The Perfect Gentleman, Edward Arnold, London, 1912, pp. 47, 49.

85 Prudence Black, personal correspondence, 19 September 2013.

86 Francine Du Plessix Grey, Them, Penguin Books, New York, 2005, p. 382.

${ }^{87}$ John Galsworthy, Swan Song, Penguin Books, London, 2007 [1928] pp. 655, 656, 663.

${ }^{88}$ Katherine Horwood, Keeping Up Appearances, The History Press, London, 2011, p. 9.

${ }^{89}$ Quoted in Horwood, pp. 111, 112.

90 Galsworthy, Swan Song, p. 792.

\section{-BIBLIOGRAPHY}

A Member of the Aristocracy, Manners and Rules of Good Society, Frederick Warne, London, 1892.

Anon., Modern Etiquette, Frederick Warne, London, c. 1890.

Anon., The American Gentleman's Guide to Politeness and Fashion,: Daley \& Jackson, New York, 1859.

Aslet, C., Anyone for England?, Little, Brown, London, 1997.

Bennett, A., The Old Wives' Tale, World's Classics, Oxford, 1995.

Bergson, B., Laughter: An Essay on the Meaning of the Comic, trans. C. Brereton and F. Rothwell, The Macmillan Co., New York, 1914, p. 3.

Breward, C., The Hidden Consumer, Manchester University Press, Manchester, 1999.

Carter, M., Putting a Face on Things, Power Institute of Fine Arts, Sydney, 1997.

Conan Doyle, A., The Complete Illustrated Sherlock Holmes, Chancellor Press, London, 1987.

Dickens, C., Bleak House, Wordsworth Classics, London, 2004.

Dickens, C., Great Expectations, Broadview Press, Peterborough, 1998.

Dickens, C., The Uncommercial Traveller, Chapman \& Hall, London, 1906.

Du Plessix Grey, F., Them, Penguin Books, New York.

Edwards, A. and D. Beyfus, Lady Behave: A Guide to Modern Manners for the '70s, Cassell, London, 1969. 
Eliot, G., Middlemarch, Norton, New York, 2000.

Fox, G.P., Fashion: The Power that Influences the World, Sheldon \& Co., London, 1872.

Galsworthy, J., Swan Song, Penguin Books, London, 2007 [1928].

Galsworthy, J., The Forsyte Saga, vol. 1, A Man of Property, Penguin Books, London, 2001.

Gissing, G., A Life's Morning, IndyPublish.com, Boston, 2012 [1888].

Graham, H., The Perfect Gentleman, Edward Arnold, London, 1912.

Hardy, T., The Hand of Ethelberta, Everyman, London, 1998.

Hardy, T., Under the Greenwood Tree, Penguin, London, 1998.

Hayter, G., The House of Commons, 1833, The National Portrait Gallery, London.

Henderson, D., Hat Talk, Wild Goose Press, Yellow Springs, Ohio, 2002.

Henry James, The American, Penguin, London, 1991.

Hitchings, H., Sorry! The English and their Manners, John Murray, London, 2013.

Hollander, A., Sex and Suits, Knopf, New York, 1994.

Horwood, K., Keeping Up Appearances, The History Press, London, 2011.

Humphry, Mrs, Manners for Men, Webb \& Bower, Exeter, 1979.

James, H., Roderick Hudson, Penguin, London, 1986.

James, H., The Princess Casamassima, Augustus Kelley, Fairfield, 1976.

Lipovetsky, G., The Empire of Fashion: Dressing Modern Democracy, trans. C. Porter, Princeton University Press, Princeton 2002.

McDowell, C., The Literary Companion to Fashion, Sinclair Stevenson, London, 1995.

Moore, G., Esther Waters, Walter Scott, London, 1894.

Raverat, G., Period Piece, Faber \& Faber, London 1954.

Sala, G.A., The Hats of Humanity, James Gee, Manchester, 1874.

Shannon, B., The Cut of his Coat, Ohio University Press, Athens, 2006.

Sherwood, Mrs J., Manners and Social Usages, Harper Bros, New York, 1884.

Steinberg, N., Hatless Jack, Granta Books, London, 2005.

Stoker, B., Dracula, Penguin Classics, London, 1993.

Thackeray, W., Vanity Fair, Penguin, London, 1968.

The Hatter's Gazette, August 1878, September 1894.

The History of Panama Hats, <www.panamahats. co.uk/pages/History-of-Panama-Hats.html>, p. 1.

The Telegraph, 28 May 2014, <www. telgraph.co.uk/menfashion-and-style/10803883/Hat-tricks-howto-look-good-in-a-hat.html>.

Wanamaker, J., The Etiquette of an Englishman's Dress, New York, 1910.

Wells, H.G., Ann Veronica, Everyman, London, 1999.

Wells, H.G., Kipps, Everyman, London, 1993.

Wells, H.G., The History of Mr Polly, Everyman, London, 1993. 
Wells, R., Manners, Culture and Dress of the Best American Society, King, Richardson \& Co., Springfield, MA, 1891.

Willet, C. and P. Cunnington, Handbook of English Costume in the 19th Century, Faber \& Faber, London, 1966.

Williams, R., Marxism and Literature, Oxford University Press, Oxford.

Willis, F., 101 Jubilee Road, Phoenix House, London, 1948.

Willis, F., A Book of London Yesterdays, Phoenix House, London, 1960. 